\title{
Effects of Nonylphenol-Induced Oxidative Stress in Ovary of Cichlid Fish, Etroplus maculatus (Bloch, 1795)
}

\author{
K.P. Asifa ${ }^{1}$, K.C. Chitra ${ }^{1 *}$ \\ ${ }^{1}$ Endocrinology and Toxicology Laboratory, Department of Zoology, University of Calicut, \\ Malappuram District, Kerala, 673 635, India
}

Tel: +91-9495135330; e-mail: kcchitra@yahoo.com

Keywords: Nonylphenol, Ovary, Etroplus maculatus, ROS, Lipid peroxidation, Antioxidant

\begin{abstract}
The present study was designed to evaluate the effects of nonylphenol in the pro-oxidant/ antioxidant system in ovary of the cichlid fish Etroplus maculatus. Fishes were exposed at two sublethal concentrations (one-fifth and one-tenth of $\mathrm{LC}_{50}$ ) of nonylphenol for 24, 72 and $96 \mathrm{~h}$ maintaining control groups. The oxidative stress indices as the activities of antioxidant enzymes, superoxide dismutase, catalase, glutathione reductase along with the levels of hydrogen peroxide generation and lipid peroxidation were monitored in concentration- and time-dependent manner. Activity of superoxide dismutase significantly $(\mathrm{P}<0.05)$ increased at both concentrations in timedependent manner. Meanwhile the activities of catalase and glutathione reductase significantly $(\mathrm{P}<0.05)$ decreased after 72 and $96 \mathrm{~h}$ of nonylphenol treatment. The levels of hydrogen peroxide generation and lipid peroxidation increased in all treatment groups when compared to controls. The present results demonstrated that the induction of oxidative stress in ovary of fish by the generation of lipid peroxidation could be due to the exposure of environmental contaminant, nonylphenol. Therefore, the observed oxidative stress in ovary can be indicated as a mechanism of toxicity in the fish exposed to nonylphenol.
\end{abstract}

\section{Introduction}

Nonylphenol (NP), a by-product of alkylphenol polyethoxylates (APEs), is widely used estrogenic non-ionic surfactants are of great concern to the society in the recent few decades. In India, the production of ethoxylates and polyethylene glycol products from a single manufacturer is with a production capacity of 70,000 metric tonnes per annum [1]. The wide range of ethoxylates meet the diversified needs of various end-use industries such as textile, pharmaceutical, personal care, emulsion polymerisation, paint, detergent, automotive, agrochemical and other industries. In the world, about 500,000 metric tonnes of APEs are produced per year and has been shown that $60 \%$ of the products get accumulated in rivers, lakes and seas [2]. Potential risk posed by environmental toxicants obviously resulted in many pathological outcomes to the exposed organisms. NP is quite common in rivers, estuaries and other aquatic bodies that receive sewage discharges or waste water effluents from the manufacturing industries [3].

Currently the Environmental Protection Agency (EPA) has accepted the risks of nonylphenol and has prepared a guideline for ambient water quality that recommends nonylphenol concentrations in freshwater be below $6.6 \mu \mathrm{g} / \mathrm{L}$ and, in saltwater, below $1.7 \mu \mathrm{g} / \mathrm{L}$ [4]. However, many other countries, including China, India and several South American countries use and produce nonylphenolic compounds in large amounts and no action has been taken to reduce or eliminate their usage [5].

The present study investigates the toxic effects of nonylphenol in cichlid fish, Etroplus maculatus. Etroplus is the genus endemic to India and it breeds throughout the year in the backwaters of Kerala [6]. It is highly sensitive species to the change in the surrounding environment and therefore used as a laboratory model to explore the effect of nonylphenol in ovary of fish. Several studies have evidenced the contaminant-stimulated reactive oxygen species (ROS) generation in ovary of fish. Short-term exposure to bisphenol A, nonylphenol and its mixture has been shown to change in the oxidative stress indices, antioxidant responses and alkaline 
phosphatase activity in zebrafish embryo [7]. The overproduction of free radicals can disrupt oocytes and reduce the fertility rate in fish. Oxidative stress occurs when the critical balance between the pro-oxidant and antioxidant is disrupted due to the overproduction of ROS [8]. Oxidative stress indices and antioxidant parameters are the potential biomarkers used as rapid screening tool to evaluate the impact of different environmental stress [9]. Therefore, the objective of the present study was to evaluate the adverse effects of nonylphenol on the induction of oxidative stress in ovary of fish.

\section{Materials and Methods}

\subsection{Animal}

Adult indigenous freshwater cichlid fish, Etroplus maculatus, $(7 \pm 0.5 \mathrm{~g} ; 7 \pm 1.5 \mathrm{~cm})$ were collected from local fish farm near Parappanangadi, Malappuram district, Kerala, India. They are brought to laboratory with least disturbance and were acclimatized to the laboratory conditions for 15 days prior to experiments by exposing to constant supply of dechlorinated water and good lighting system. Fish were maintained in well-aerated aquarium tanks (40 L capacity) and health status of the animal was continuously monitored throughout the experiment.

\subsection{Preliminary tests}

All physico-chemical features of the tap water were estimated according to the standardized procedures recommended by APHA [10]. Accordingly, standard water temperature $\left(28 \pm 2{ }^{\circ} \mathrm{C}\right)$, oxygen saturation of water (70 and $100 \%), \mathrm{pH}(6.5$ to 7.5$)$ was maintained throughout the experiment in both control and treatment groups.

\subsection{Chemicals}

Technical grade Nonylphenol, 4-(2, 4-dimethylheptan-3-yl) phenol of 97\% purity was purchased from SISCO Research Laboratories Pvt. Ltd., Mumbai, India. Malondialdehyde, NADPH, glutathione oxidized, thiobarbituric acid and pyrogallol were obtained from Himedia Laboratories, Mumbai, India. All other chemicals were of analytical grade and obtained from local commercial sources.

\subsection{Treatment}

After acclimatization, fishes were grouped into various groups in different tanks by maintaining ten animals per group. Nonylphenol was dissolved in 1\% DMSO and therefore used as a solvent (vehicle) control in the experiment. In the treatment groups, two sub-lethal concentrations such as one-fifth $(178 \mu \mathrm{g} / \mathrm{L})$ and one-tenth $(89 \mu \mathrm{g} / \mathrm{L})$ of $\mathrm{LC}_{50}-96 \mathrm{~h}$ concentrations were used. The duration of nonylphenol exposure was selected for 24,72 and $96 \mathrm{~h}$ maintaining negative and positive controls. The plan of the experiment is described as follows:

Group I - Solvent-free (only water)

Group II - With solvent (1\% DMSO)

Group III - Treatment Groups: One-fifth of $\mathrm{LC}_{50}-96 \mathrm{~h}$ of nonylphenol $(178 \mu \mathrm{g} / \mathrm{L})$

Group IIIA - NP at $178 \mu \mathrm{g} / \mathrm{L}$ for $24 \mathrm{~h}$

Group IIIB - NP at $178 \mu \mathrm{g} / \mathrm{L}$ for $72 \mathrm{~h}$

Group IIIC - NP at $178 \mu \mathrm{g} / \mathrm{L}$ for $96 \mathrm{~h}$

Group IV - Treatment Groups: One-tenth of $\mathrm{LC}_{50}-96 \mathrm{~h}$ of nonylphenol $(89 \mu \mathrm{g} / \mathrm{L})$

Group IVA - NP at $89 \mu \mathrm{g} / \mathrm{L}$ for $24 \mathrm{~h}$

Group IVB - NP at $89 \mu \mathrm{g} / \mathrm{L}$ for $72 \mathrm{~h}$

Group IVC - NP at $89 \mu \mathrm{g} / \mathrm{L}$ for $96 \mathrm{~h}$

At the end of every experiment, fishes were caught very gently using a small dip net, one at a time with least disturbance and were decapitated. Ovary were dissected and stored at $4^{\circ} \mathrm{C}$ until the biochemical analyses were performed. A $1 \%(\mathrm{w} / \mathrm{v})$ homogenate of ovary was prepared in ice-cold normal saline with the help of a motor-driven glass Teflon homogenizer on crushed ice for a minute. The homogenate was centrifuged at $8000 \mathrm{~g}$ for $15 \mathrm{~min}$ at $4^{\circ} \mathrm{C}$ to obtain the supernatant, 
which was then used for the biochemical analyses. Protein was estimated by the method of Lowry et al. [11] with BSA as the standard. Activity of superoxide dismutase [12], catalase [13], glutathione reductase [14], level of hydrogen peroxide generation [15], level of lipid peroxidation [16] were measured in crude homogenate.

\subsection{Statistical analyses}

Statistical analyses were performed using one-way analysis of variance (ANOVA) followed by Duncan's Multiple Range test using statistical package SPSS 19.0. Differences were considered to be significant at $\mathrm{p}<0.05$ against control group. Data are presented as mean \pm SD for ten animals per group. All biochemical estimations were carried out in duplicate.

\section{Results and Discussion}

In ecotoxicology, assessing the correlation between the effects of environmental contaminant and the elevation of reactive oxygen species is the most concerned issue. The reason is that most of the toxicant-related oxidative stress leads to various dysfunction of reproductive system in fishes as decreased sperm number and motility, development of ovo-testis, inhibition of spermiogenesis, and sperm-oocyte fusion in males [17]. In females, the decrease in production of egg, infertility, induction of plasma vitellogenin and zona radiata proteins and imbalance in sex hormones has been reported $[18,19]$. The present findings mainly focussed on the adverse effects of one of the environmental contaminants, nonylphenol in the induction of oxidative stress in ovary of cichlid fish, Etroplus maculatus.

The median lethal concentration $\left(\mathrm{LC}_{50}-96 \mathrm{~h}\right)$ of nonylphenol in E. maculatus was determined from our laboratory by using probit analysis as $890 \mu \mathrm{g} / \mathrm{L}$ [20]. Two sublethal concentrations, one-fifth and one-tenth of $\mathrm{LC}_{50}-96 \mathrm{~h}$ was chosen in the present study. After $96 \mathrm{~h}$ of NP treatment the activity of superoxide dismutase significantly $(\mathrm{P}<0.05)$ increased at both concentrations in time-dependent manner (Table 1 and 2).

Among the antioxidant enzymes, superoxide dismutase is the first defensive barrier against the free radicals, where it converts superoxide into hydrogen peroxide [21]. In the present study nonylphenol exposure could have elevated the activity of superoxide dismutase to overcome the toxicant-related stress. However, the activities of catalase and glutathione reductase significantly $(\mathrm{P}<0.05)$ decreased after 72 and $96 \mathrm{~h}$ of nonylphenol treatment at both concentrations (Table 1 and 2).

Table 1. Effect of nonylphenol (one-fifth of $\mathrm{LC}_{50}-96 \mathrm{~h}$ concentration) on antioxidant parameters in ovary of cichlid fish, Etroplus maculatus (Mean \pm SD)

\begin{tabular}{|l|l|l|l|l|l|}
\hline \multicolumn{1}{|c|}{ Parameters } & \multirow{2}{*}{ Control } & \multirow{2}{*}{ Vehicle } & \multicolumn{3}{c|}{ Nonylphenol (178 $\mathbf{~ g / ~ L ) ~}$} \\
\cline { 4 - 6 } & & & $\mathbf{2 4} \mathbf{~ h}$ & \multicolumn{1}{|c|}{$\mathbf{~ h}$} & \multicolumn{1}{|c|}{$\mathbf{~ h}$} \\
\hline Superoxide dismutase [a] & $5.37 \pm 0.54$ & $5.07 \pm 0.22$ & $7.14 \pm 0.28^{*}$ & $9.09 \pm 0.42^{*}$ & $11.16 \pm 0.51^{*}$ \\
\hline Catalase [b] & $5.83 \pm 0.27$ & $5.85 \pm 0.30$ & $5.72 \pm 0.39$ & $3.75 \pm 0.38^{*}$ & $1.70 \pm 0.46^{*}$ \\
\hline Gutathione reductase [c] & $6.65 \pm 0.30$ & $6.76 \pm 0.24$ & $4.14 \pm 0.36^{*}$ & $2.47 \pm 0.16^{*}$ & $1.49 \pm 0.20^{*}$ \\
\hline Hydrogen peroxide [d] & $3.79 \pm 0.19$ & $3.90 \pm 0.20$ & $7.71 \pm 0.47^{*}$ & $11.09 \pm 0.61^{*}$ & $13.97 \pm 0.66^{*}$ \\
\hline Lipid peroxidation [e] & $4.23 \pm 0.37$ & $4.13 \pm 0.41$ & $6.72 \pm 0.38^{*}$ & $8.49 \pm 0.35^{*}$ & $12.58 \pm 0.40^{*}$ \\
\hline
\end{tabular}

[a] nmol pyrogallol oxidized/ $\mathrm{min} / \mathrm{mg}$ protein

[b] $\quad \mu \mathrm{mol} \mathrm{H}_{2} \mathrm{O}_{2}$ consumed/ $\mathrm{min} / \mathrm{mg}$ protein

[c] nmol NADPH oxidized/ $\mathrm{min} / \mathrm{mg}$ protein

[d] $\quad \mathrm{nmol} \mathrm{H}_{2} \mathrm{O}_{2}$ produced/ min/ mg protein

[e] $\quad \mu \mathrm{mol}$ malondialdehyde produced/ $\mathrm{mg}$ protein

Asterisks [*] denotes significant at $\mathrm{P}<0.05$ against control groups 
Table 2. Effect of nonylphenol (one-tenth of $\mathrm{LC}_{50}-96 \mathrm{~h}$ concentration) on antioxidant parameters in ovary of cichlid fish, Etroplus maculatus (Mean \pm SD)

\begin{tabular}{|l|c|l|l|c|c|}
\hline \multicolumn{1}{|c|}{ Parameters } & Control & Vehicle & \multicolumn{3}{c|}{ Nonylphenol (89 $\mathbf{~ g / ~ L ) ~}$} \\
\cline { 4 - 6 } & & & $\mathbf{2 4} \mathbf{~ h}$ & $\mathbf{7 2 ~ h}$ & $\mathbf{9 6} \mathbf{~ h}$ \\
\hline Superoxide dismutase [a] & $5.37 \pm 0.54$ & $5.07 \pm 0.22$ & $6.68 \pm 0.17^{*}$ & $7.60 \pm 0.79^{*}$ & $9.06 \pm 0.21^{*}$ \\
\hline Catalase [b] & $5.83 \pm 0.27$ & $5.85 \pm 0.30$ & $5.93 \pm 0.38$ & $5.02 \pm 0.33^{*}$ & $4.67 \pm 0.24^{*}$ \\
\hline Gutathione reductase [c] & $6.65 \pm 0.30$ & $6.76 \pm 0.24$ & $6.21 \pm 0.39$ & $5.18 \pm 0.17^{*}$ & $4.37 \pm 0.38^{*}$ \\
\hline Hydrogen peroxide [d] & $3.79 \pm 0.19$ & $3.90 \pm 0.20$ & $5.04 \pm 0.51$ & $8.33 \pm 0.31^{*}$ & $9.87 \pm 0.49^{*}$ \\
\hline Lipid peroxidation [e] & $4.23 \pm 0.37$ & $4.13 \pm 0.41$ & $5.02 \pm 0.30$ & $6.21 \pm 0.21^{*}$ & $10.23 \pm 0.38^{*}$ \\
\hline
\end{tabular}

[a] nmol pyrogallol oxidized/ $\mathrm{min} / \mathrm{mg}$ protein

[b] $\quad \mu \mathrm{mol} \mathrm{H}_{2} \mathrm{O}_{2}$ consumed $/ \mathrm{min} / \mathrm{mg}$ protein

[c] nmol NADPH oxidized/ $\mathrm{min} / \mathrm{mg}$ protein

[d] $\mathrm{nmol} \mathrm{H}_{2} \mathrm{O}_{2}$ produced/ $\mathrm{min} / \mathrm{mg}$ protein

[e] $\quad \mu \mathrm{mol}$ malondialdehyde produced/ mg protein

Asterisks [*] denotes significant at $\mathrm{P}<0.05$ against control groups

This could be due to the failure of the enzymes to eliminate the free radicals and it ultimately led to the elevated levels of hydrogen peroxide generation and lipid peroxidation in ovary of all treatment groups when compared to controls (Table 1 and 2). Hydrogen peroxide is degraded by catalase and glutathione reductase/ peroxidase system using reduced glutathione. The reduction is the activity of catalase and glutathione reductase reflects the inability of ovarian tissue to eliminate hydrogen peroxide.

Lipid peroxidation is the well recognized mechanism to assess cellular injury in animals and it is used as indicator of oxidative stress in cells and tissues. It is self-perpetuating free-radical mediated chain reaction and its length of propagation depends on the activities of antioxidant enzymes [22]. Increase in the lipid peroxidation with the increase in time and concentrations suggest the degree of damage to ovarian tissue in response to nonylphenol exposure. The adverse effect of nonylphenol was hence clearly known by the alteration in the antioxidant defence system in ovary of fish.

\section{Conclusions}

The observation appears convincing to speculate that acute exposure to nonylphenol for $96 \mathrm{~h}$ induced oxidative stress in ovarian tissue of fish. The oxidative damage caused to ovary could be due to the alteration in redox status and total antioxidant capacity of ovarian tissue. However, the intensity of tissue damage due to toxicant-induced oxidative stress could be further justified by chronic nonylphenol exposure.

\section{Acknowledgement}

The study was funded by Kerala State Council for Science, Technology and Environment (KSCSTE), Thiruvananthapuram, Kerala, India.

\section{References}

[1] PARCOM 92/8. Recommendation on nonylphenol-ethoxylates, London, UK. OSPAR Convention, 2000.

[2] R. Renner, European bans on surfactant trigger transatlantic debate, Environ. Sci. Technol. 31 (1997) 316-320.

[3] J. Brendehaug et al., Toxicity testing and chemical characterisation of produced water-a preliminary study, Environ. Sci. Res. 46 (1992) 245-256. 
[4] L. Brooke, G. Thursby, Ambient aquatic life water quality criteria for nonylphenol. Washington DC, USA: Report for the United States EPA, Office of Water, Office of Science and Technology, 2005.

[5] A. Soares et al., Nonylphenol in the environment: A critical review on occurrence, fate, toxicity and treatment in wastewaters, Environ. Int. 34 (2008) 1033-1049.

[6] V. Jayaprakas, K. G. Padmanabhan, N. K. Balasubramanian, Food, feeding habits and breeding biology of the orange chromide Etroplus maculatus (Bloch), Bulletin of the Department of Aquatic Biology, University of Kerala, India. 4 (1979) 9-21.

[7] M. Wu et al., Oxidative stress in zebrafish embryos induced by short-term exposure to bisphenol A, nonylphenol, and their mixture, Environ. Toxicol. Chem. 30 (2011) 23352341.

[8] B. P. Yu, Cellular defenses against damage from reactive oxygen species, Physiol. Rev. 74 (1994) 139-162.

[9] A. Valavanidis et al., Molecular biomarkers of oxidative stress in aquatic organisms in relation to toxic environmental pollutants, Ecotoxicol. Environ. Saf. 64 (2006) 178-189.

[10] APHA. Standard methods for the examination of water and waste water, 20th Edition, Washington, DC., 1998.

[11] O.H. Lowry et al., Protein measurement with the Folin phenol reagent, J. Biol. Chem. 193 (1951) 265-275.

[12] S. Marklund, G. Marklund, Involvement of superoxide anion radical in antioxidation of pyrogallol and a constituent assay for superoxide dismutase, Eur. J. Biochem. 47 (1974) 469-474.

[13] A. Claiborne, Catalase activity. In: CRC Handbook of methods for oxygen radical research. R Greenwald (ed.), CRC Press, Boca Raton, Florida, 1985, pp 283-284.

[14] I. Carlberg, B.J. Mannervik, Purification and characterization of the flavoenzyme glutathione reductase from rat liver, J. Biol. Chem. 250 (1985) 5474-5480.

[15] E. Pick, Y. Keisari, Superoxide anion and $\mathrm{H} 2 \mathrm{O} 2$ production by chemically elicited peritoneal macrophages-induced by multiple nonphagocytic stimuli, Cell. Immunol. 59 (1981) 301-318.

[16] H. Ohkawa, N. Ohishi, K. Yagi, Assay for lipid peroxidation in animal tissues by thiobarbituric acid reaction, Anal. Biochem. 95 (1979) 351-358.

[17] R.H. Devlin, Y. Nagahama, Sex determination and sex differentiation in fish: an overview of genetic, physiological and environmental influences, Aquaculture. 208 (2002) 191-364.

[18] D.E. Kime, J.P. Nash, A.P. Scott, Vitellogenesis as a biomarker of reproductive disruption by xenobiotics, Aquaculture. 177 (1999) 345-352.

[19] F. Lahnsteiner et al., The effect of 4-nonylphenol on semen quality, viability of gametes, fertilization success, and embryo and larvae survival in rainbow trout (Oncorhynchus mykiss), Aquatic Toxicology. 71 (2005) 297-306.

[20] K.P. Asifa, P.V. Vidya, K.C. Chitra, Assessment of median lethal concentration ( $\left.\mathrm{LC}_{50}-96 \mathrm{~h}\right)$ and behavioural modification of nonylphenol in the cichlid fish, Etroplus maculatus (Bloch, 1795), Int. J. Adv. Life Sci. (2016) (In press)

[21] S. Pandey et al., Biomarkers of oxidative stress: A comparative study of river Yumuna fish Wallago attu (Bl. and Schn.), Sci. Total Environ. 309 (2003) 105-115.

[22] B. Halliwell, J.M.C. Gutteridge, Free radicals in biology and medicine. Oxford University Press, Oxford, 1999. 